\title{
Review
}

\section{Selectins: functional importance as cell adhesion molecule in immune system}

\author{
Yunjeong Noh, Donghyun Cho ${ }^{1}$, Haesu Ko ${ }^{1}$, Dajeong Lim ${ }^{1}$, Han-Ha Chai ${ }^{1}{ }^{2 *}$ \\ ${ }^{1}$ National Institute of Animal Science, RDA, Wanju 55365, Korea \\ ${ }^{2}$ College of Pharmacy, Chonnam National University, Gwangju 61186, Korea
}

Selectins are cell membrane glycoproteins that recognize specific glycoconjugates expressed on the surface of cells. Then, selectins adjust cell-cell interactions that are important in inflammation, hemostasis and cancer metastasis. Selectins mediate leukocyte calls to move into the site of inflammation through interactions with activated endothelial cells or endogenous selectin ligands expressed in high endothelial venules. Types of selectins are divided into L-selectin, E-selectin and P-selectin, which are called to CD62L, CD62E, and CD62P, respectively. Each selectin is composed of four regions; the C-type lectin region of $\mathrm{N}$-terminal, the epidermal growth factor (EGF) region, the intracellular $\mathrm{C}$-terminal region, and the hydrophobic transmembrane region. They have similar structures but differ in their binding specificities and tissue distributions. The selectin family commonly recognizes the sialyl Lewis X (sLeX) on carbohydrate structures. Although biological ligands bound to each selectin are different from each other, they commonly bind to P-selectin glycoprotein ligand-1 (PSGL-1) ligand. The PSGL-1 ligand is a glycoprotein promoting cell adhesion in inflammatory responses. If the absence of selectins and their ligands in humans and animals are, should lead to persistent infections and diseases. Selectin family must be considered as a key subject for drug discovery since they have various functions depending on the ligand which they bind to.

Key word: selectin, L-selectin, E-selectin, P-selectin, inflammation

\section{Introduction}

염증(inflammation)은 조직 손상 및 감염과 같은 유해한
자극에 의해 유발되는 면역반응이다[1]. 우리 몸에서 염증반 응이 일어나면, 혈류를 통하여 체내를 순환하는 백혈구들은 염증 부위로부터 나오는 신호에 반응하여 순차적인 부착 (adhesion)과 E-셀렉틴(E-selectin) 신호전달과정을 거쳐 이 동한다. 이때 호중성백혈구(neutrophil)는 활성화된 혈관내피 세포(endothelial cell)에서 발현되는 P-셀렉틴(P-selectin)과 $\mathrm{E}$-셀렉틴에 부착하여 혈관내피세포 위를 구르게 된다(adhesion rolling). P-셀렉틴에 대해 호중성백혈구는 PSGL-1(P-selectin glycoprotein ligand-1)이라는 리간드를 이용하고, E-셀렉틴에 대해서는 PSGL-1, CD44 등 E-셀렉틴 리간드를 이용한다 (Table 1). 혈관내피세포 위를 구르는 백혈구는 G-단백질 수 용체(G-coupled receptor)를 통해 케모카인(chemokine)에 반 응하게 되고, 인테그린 alphaLbeta2(LFA-1, CD11a/CD18), alphaMbeta2(Mac-1, CD11b/CD18)와 결합력(affinity)이 증 가한다(Fig. 1). LFA-1과 Mac-1에 대한 강한 친화력으로 ICAM-1(intracellular adhesion molecule-1)에 부착하여 백혈 구는 더 천천히 구르기하다가 염증 부위에서 결국 혈관 밖 으로 유출(extravasation)하게 된다[2]. 대부분의 세포부착분 자(cell adhesion molecule, $\mathrm{CAM}$ )들은 셀렉틴 군(selectin family), 뮤신-유사 군(mucin-like family), 인테그린 군(integrin family)및 면역글로불린 슈퍼패밀리(immunoglobulin superfamily) 등 4종류의 단백질 그룹에 속한다. 막당단백질(membrane glycoprotein)에 속하는 셀렉틴 군은 세포외 렉틴-유사 영역 (extracellular lectin-like domains)을 갖고 있어서 뮤신-유사 단백질들과 결합을 할 수 있다. 셀렉틴 군에는 L-셀렉틴, E셀렉틴, 그리고 $\mathrm{P}$-셀렉틴 등의 3 가지로 구성되며, 이들은 각 각 $\mathrm{CD} 62 \mathrm{~L}, \mathrm{CD} 62 \mathrm{E}$ 및 $\mathrm{CD} 62 \mathrm{P}$ 등으로 부른다. 각 셀렉틴은 $\mathrm{N}$-말단 영역에 $\mathrm{C}$ 형-렉틴 도메인, 칼슘 의존 $\left(\mathrm{Ca}^{2+}\right)$ 을 특징으 로 하는 EGF-like 도메인(epidermal growth factor, EGF), 짧 은 보존 반복 구조(short consensus repeats, Sushi domain)에 막관통(transmembrane, $\mathrm{TM}$ ) 도메인 그리고 $\mathrm{C}$-말단 세포질

${ }^{*}$ Corresponding author: Han-Ha Chai

College of Pharmacy, Chonnam National University, Gwangju, 61186, Korea

Tel: +82-63-238-7307, E-mail: hanha@korea.kr 
Table 1. Selectin family

\begin{tabular}{cclcc}
\hline Types & Mole & \multicolumn{1}{c}{ Expression } & Ligands & Function \\
\hline $\begin{array}{c}\text { L-selectin } \\
\text { (CD62L) }\end{array}$ & $65-75 \mathrm{kDa}$ & Various leukocytes & $\begin{array}{c}\text { GlyCAM-1, } \\
\text { CD34, PSGL-1 }\end{array}$ & Mediates of leukocyte-endothelial interactions \\
$\begin{array}{c}\text { E-selectin } \\
\text { (CD62E) }\end{array}$ & $116 \mathrm{kDa}$ & $\begin{array}{l}\text { Endothelium activated by infla- } \\
\text { mmatory mediators }\end{array}$ & $\begin{array}{c}\text { ESL-1, CD44, } \\
\text { Mac-2BP, PSGL-1 }\end{array}$ & Recruiting leukocytes to the site of injury \\
$\begin{array}{l}\text { P-selectin } \\
\text { (CD62P) }\end{array}$ & $140 \mathrm{kDa}$ & $\begin{array}{l}\text { Endothelium activated by infla- } \\
\text { mmatory stimuli }\end{array}$ & $\begin{array}{c}\text { ESL-1, PSGL-1 } \\
\text { Initial recruitment of leukocytes to the } \\
\text { site of injury during inflammation }\end{array}$ \\
\hline
\end{tabular}

glyCAM-1, glycosylation-dependent cell adhesion molecule-1; PSGL-1, P-selectin glycoprotein ligand-1; ESL-1, E-selectin ligand-1; Mac-2BP, Mac-2 binding protein.

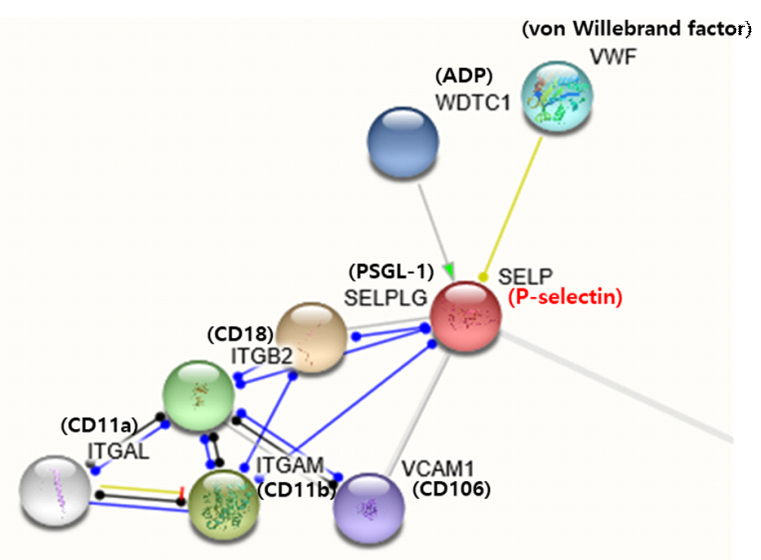

Fig. 1. Genes that interact with P-selectin. Genes associated with P-selectin interact with each other to show a variety of functions. Among the genes that bind to P-selectin, VWF interacts with P-selectin to be fixed on the surface of the cell, and SELPLG is a P-selectin glycoprotein ligand-1 (PSGL-1), and is expressed in leukocyte and serves to recruit leukocyte cells to inflamed tissue.

도메인을 지닌 구조이다(Fig. 2). 특히, EGF 도메인은 셀렉 틴의 리간드가 결합하는 부위이다. P-와L-셀렉틴은 유사한 단백질 3차-구조를 갖지만, 동일한 구조를 갖지 않는다. 예 를 들어 돼지 E-셀렉틴는 6개 Sushi 도메인이 반복되는 구 조를 갖고 있지만, P-셀렉틴은 9개 Sushi 도메인이 반복되고 $\mathrm{L}$-셀렉틴은 2 개 Sushi 도메인으로 구성되어 있다. E-와 L-셀 렉틴의 Sushi 도메인의 적은 반복은 리간드 결합 친화성을 증가시킨다. E-셀렉틴은 주로 염증 조직 내 혈관내피세포에 서 발현되어 백혈구-혈관내피세포 부착에 관여하지만, L-셀 렉틴은 B-세포, T-세포, 단핵구, 과립구 일부 $\mathrm{NK}$-세포에 주 로 발현이 된다. L-셀렉틴은 백혈구-혈관내피세포 부착이외 에 미감작 $\mathrm{T}$-세포의 말초림프절 흐름에도 관여를 한다. $\mathrm{P}$-셀 렉틴은 혈소판, 혈관내피세포의 과립내 존재하다가 활성화 되면서 세포표면으로 수송된다. 주로 혈관내피세포, 혈소판 에 대한 백혈구 부착(CD162)에 결합한다(Fig. 1). 셀렉틴들 은 염증 반응 시 백혈구가 내피세포에 결합하는 초기단계에
중요한 분자들이며, 백혈구의 귀소(homing) 과정에도 중요 한 역할을 한다[3].

세포 부착은 세포의 이동, 분화 및 신호전달 등 세포 기 능을 조절하며, 세포부착분자는 염증, 암 전이 및 상처 치유 등 여러 면역계에 관여하기 때문에 세포 부착 분자의 발현 이 여러 질병에 관여한다[4]. 세포부착분자인 셀렉틴은 다양 한 질병에 관여하기 때문에[5], 인간과 동물에게 어떠한 영 향을 끼치는지에 대해 셀렉틴의 기능을 중심으로 설명하고 자 한다.

\section{Discussion}

\section{L-selectin}

$\mathrm{CD} 62 \mathrm{~L}$ 이라고 불리는 백혈구 부착 수용체인 $\mathrm{L}$-셀렉틴은 림프절의 표면에서 림프절 귀소수용체, 내피세포에 대한 백 혈구 부착을 조절하는 데 중요한 역할을 한다. LECAM-1, MEL-14 항원, gp90MEL, LAM-1, Leu-8과 DREG 항원 등 으로 불리며, 세포-세포 접착 단백질인 셀렉틴 계열에 속한 다. 염증의 림프절 외부에서 림프구내 백혈구와 혈관 내피 의 상호작용을 연결해 주며, 림프절내 렉틴-유사 수용체로 림프절의 고내피세정맥(high endothelial venules, HEV)과 림프구 간의 초기 상호작용을 매개한다 $[6,7] . \mathrm{L}$-셀렉틴은 백혈구의 구르기에 관여하고 활성화되면 백혈구 표면으로부 터 배출되는 기능을 가지고 있다. L-셀렉틴의 가교결합에 의해 유도되는 L-셀렉틴의 흘림(shedding)이 백혈구의 구르 기 속도를 조절하기 때문에, 백혈구가 염증 부위로 이동하 는 과정에서 L-셀렉틴의 중요한 역할을 알 수 있다[8]. 또한 인간의 혈장으로부터 $50-170 \mathrm{kDa}$ 까지 다양한 크기의 단백 질이 분리되어 있고[9], 말초 림프절 및 점막 림프절의 $\mathrm{HEV}$ 에서 발현한다. 말초 림프절에서 $\mathrm{L}$-셀렉틴의 당단백질 리간 드인 $50 \mathrm{kDa}$ 와 $90 \mathrm{kDa}$ 의 황산화당단백질(sulphated glycoprotein, $\operatorname{sgp)ㅇㅡㄹ~ㅎㅘㄱㅇㅣㄴㅎㅏㅇㅕㅆㄱㅗ,~ㄱㅏㄱㄱㅏㄱ~} \operatorname{sgp} 50$ 과 sgp90으로 부른다. Sgp50 은 glyCAM-1(glycosylation-dependent cell adhesion molecule-1) 로 명명되고, sgp90은 시알로뮤신 당단백질 CD34로 확인되 었으며, 말초 림프절 및 기타 조직의 $\mathrm{HEV}$ 의 표면에서 발견 
(A)

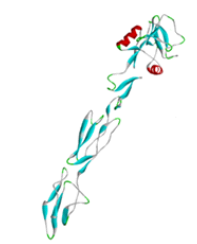

L-selectin(C)(21)

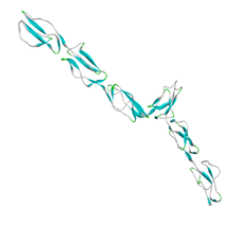

P-selectin (CD62P)

(B)

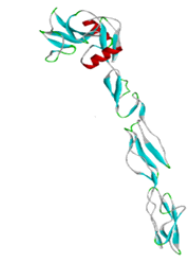

E-selectin(CD62E)

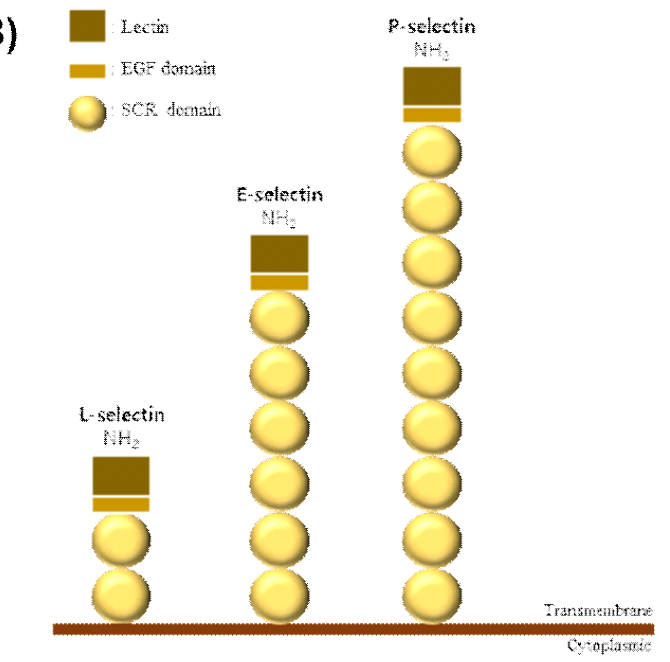

Fig. 2. (A) Protein structure of selectins. (B) Structure of selectins. L-selectin has two SCR domains, E-selectin has six, and P-selectin has nine SCR domains.

되었다[10, 11]. GlyCAM-1은 말초 림프절(peripheral lymph nodes, PLN)과 장간막 림프절(mesenteric lymph nodes, $\mathrm{MLN})$ 의 고 내피세정맥에서 생산된다. CD34는 인간의 골수 줄기세포를 정제하는데 사용되었으며, 인간 여러 장기의 혈관 내피에 존재한다[12]. L-셀렉틴은 백혈구를 감염 및 염증 부 위로 유도하고, 염증성 사이토카인인 TNF- $\alpha$ (tumor necrosis factor- $\alpha$ )는 L-셀렉틴 리간드의 발현을 자극하여 백혈구 부 착을 증가시킨다[13]. 인간 결장암 세포주에 대한 연구에서, $\mathrm{L}$-셀렉틴 발현 조절한 마우스를 통해 암 전이가 억제되는 것을 확인하였다[14].

\section{E-selectin}

내피 백혈구 부착 분자(endothelial leukocyte adhesion molecule-1, ELAM-1)라고 알려진 E-셀렉틴(CD62E)은 $116 \mathrm{kDa}$ 당단백질로 $\mathrm{Ca}^{2+}$ 에 의존적으로 탄수화물에 결합하는 $\mathrm{C}$-형 동물 렉틴이다. IL-1(interleukin-1), LPS(lipopolysaccharides) 또는 $\mathrm{TNF}$ 와 같은 사이토카인(cytokine)에 의해 내피세포에 발현되고, 단핵세포, 기억 T세포 및 호중구의 부착을 촉진시 킨다[15-17]. 동물모델에서는 E-셀렉틴이 호중구의 이동에 관여한다[18]. E-셀렉틴은 다양한 리간드가 존재하고, 부분 적으로 탄수화물 구조를 갖는다. E-셀렉틴의 리간드는 탄수화물 구조의 $\mathrm{SLe}^{\mathrm{x}}$ (sialy Lewis $\mathrm{x}$ )를 인식하며, $\mathrm{SLe}^{\mathrm{x}}$ 또는 $\mathrm{SLe}^{\mathrm{a}}$ (sialy Lewis a)를 포함하는 네오글리코단백질(neoglycoprotein) 에 결합하여 올리고당표면과 상호작용을 하여, 말단 시알산 (sialic acid)과 푸코오스(fucose) 잔여물을 제공한다[19]. 그 외에도 $\mathrm{CD} 44$, Mac-2BP(Mac-2 binding protein), Muc-1, DR3 (death receptor-3), ESL-1(E-selectin ligand-1) 리간드가 다른 세포들에서 동정되었고[20], 그 중 ESL-1은 쥐의 골수 세포 와 E-셀렉틴 결합에 관여하는 고친화성 당단백질 리간드이다.
ESL-1은 E-셀렉틴에 대한 세포결합을 매개하며[21], CD44 는 E-셀렉틴에 결합하여 백혈구의 구르기 속도를 조절한다[22]. $\mathrm{CD} 44$ 와 Mac-2BP는 유방암 세포주에서 발현되며, DR3는 결장암 세포에서 발현된다[23-25]. 이 외에도 암세포에 의해 발현되는 E-셀렉틴의 리간드는 여러 가지 암세포 전이 과정 에 관여하며, 순환하는 암세포와 내피세포에 대한 부착뿐만 아니라, 종양의 악화에도 중요한 매개체이다[26]. 암세포 상 에 존재하는 $\mathrm{E}$-셀렉틴과 $\mathrm{DR} 3$ 의 상호작용은 형질전환된 세 포의 운동성과 생존을 향상되도록 세포 내 신호를 자극한 다. 이러한 결과로 보아 E-셀렉틴은 내피세포 활성화 마커로 작용할 수 있다[14]. 또한 백혈병 형태의 나병에서 관찰된 E셀렉틴 발현 결핍은 조직의 면역력을 손상시킨다[27].

\section{P-selectin}

활성화된 혈소판 및 내피세포에서 발현되는 P-셀렉틴 (CD62P)은 단핵구와 호중구의 표면에 탄수화물을 결합하는 렉틴으로, 단핵세포와 호중구의 세포부착을 매개하고[28], 특정 백혈구와 혈소판의 내피에 접착을 부분적으로 담당하 는 세포부착분자이다. P-셀렉틴은 3 가지 셀렉틴 중에서 가 장 큰 질량인 $140 \mathrm{kDa}$ 의 크기를 가지는 단백질로 내피 표면 에서 약 $40 \mathrm{~nm}$ 까지 확장되며, 내피세포의 분비형 과립(weibelpalade body)과 혈소판의 알파 과립(alpha granules)에 저장 된다[29, 30]. P-셀렉틴은 암세포에 활성화된 혈소판의 응집 과 자극된 내피세포에 암세포의 부착을 매개하며 결장암, 폐암, 위암, 신경 모세포종 및 악성 흑색종 등과 같은 여러 암세포주에 결합한다[31]. PSGL-1은 $O$-glyocosylated mucinlike 구조의 $110 \mathrm{kDa}$ homodimeric strain이며, 백혈구에서 P-셀렉틴의 리간드로 발현한다. PSGL-1은 모세혈관 아래에 서 정상 백혈구의 구르기(rolling) 현상을 위해 필요하며, $\mathrm{T}$ 
Table 2. Function of selectin genes

\begin{tabular}{clcc}
\hline (A) Biological process during GO ontology analysis of selectin genes & & \\
\hline \multirow{2}{*}{ GO-term } & \multicolumn{1}{c}{ Description } & $\begin{array}{c}\text { Count in } \\
\text { gene set }\end{array}$ & False discovery rate \\
\hline GO:0032802 & Low-density lipoprotein particle receptor catabolic process & 5 of 10 & $1.01 \mathrm{e}-10$ \\
GO:0072583 & Clathrin-dependent endocytosis & 5 of 24 & $1.32 \mathrm{e}-09$ \\
GO:0034383 & Low-density lipoprotein particle clearance & 5 of 24 & $1.32 \mathrm{e}-09$ \\
GO:0050690 & Regulation of defense response to virus by virus & 5 of 30 & $1.80 \mathrm{e}-09$ \\
GO:0043112 & Receptor metabolic process & 6 of 95 & $2.42 \mathrm{e}-09$ \\
\hline
\end{tabular}

(B) Molecular function during GO ontology analysis of selectin genes

\begin{tabular}{|c|c|c|c|}
\hline GO-term & Description & $\begin{array}{l}\text { Count in } \\
\text { gene set }\end{array}$ & False discovery rate \\
\hline GO:0050839 & Cell adhesion molecule binding & 4 of 200 & 0.00032 \\
\hline GO:0044877 & Protein-containing complex binding & 6 of 968 & 0.00032 \\
\hline GO:0035615 & Clathrin adaptor activity & 2 of 8 & 0.00032 \\
\hline GO:0030369 & ICAM-3 receptor activity & 2 of 3 & 0.00032 \\
\hline GO:0030276 & Clathrin binding & 3 of 63 & 0.00032 \\
\hline \multicolumn{4}{|c|}{ (C) Cellular component during GO ontology analysis of selectin genes } \\
\hline GO-term & Description & $\begin{array}{l}\text { Count in } \\
\text { gene set }\end{array}$ & False discovery rate \\
\hline GO:0030122 & AP-2 adaptor complex & 5 of 8 & $9.86 \mathrm{e}-12$ \\
\hline GO:0036020 & Endolysosome membrane & 5 of 15 & $2.96 \mathrm{e}-11$ \\
\hline GO:0098797 & Plasma membrane protein complex & 9 of 502 & $9.77 \mathrm{e}-11$ \\
\hline GO:0030659 & Cytoplasmic vesicle membrane & 9 of 724 & $1.03 \mathrm{e}-09$ \\
\hline GO:0030136 & Clathrin-coated vesicle & 6 of 172 & $7.10 \mathrm{e}-09$ \\
\hline \multicolumn{4}{|c|}{ (D) KEGG pathways of selectin gene } \\
\hline Pathway & Description & $\begin{array}{l}\text { Count in } \\
\text { gene set }\end{array}$ & False discovery rate \\
\hline hsa05150 & Staphylococcus aureus infection & 5 of 51 & $4.95 \mathrm{e}-09$ \\
\hline hsa04961 & Endocrine and other factor-regulated calcium reabsorption & 5 of 47 & $4.95 \mathrm{e}-09$ \\
\hline hsa04721 & Synaptic vesicle cycle & 5 of 61 & $4.95 \mathrm{e}-09$ \\
\hline hsa04514 & Cell adhesion molecules (CAMs) & 6 of 139 & $4.95 \mathrm{e}-09$ \\
\hline hsa05144 & Malaria & 4 of 47 & $2.07 \mathrm{e}-07$ \\
\hline \multicolumn{4}{|c|}{ (E) Reactome pathways of selectin genes } \\
\hline Pathway & Description & $\begin{array}{l}\text { Count in } \\
\text { gene set }\end{array}$ & False discovery rate \\
\hline hsa182218 & Nef mediated CD8 Down-regulation & 5 of 7 & $3.09 \mathrm{e}-12$ \\
\hline hsa167590 & Nef mediated CD4 Down-regulation & 5 of 9 & $4.93 \mathrm{e}-12$ \\
\hline has 8866427 & VLDLR internalisation and degradation & 5 of 12 & $1.02 \mathrm{e}-11$ \\
\hline hsa5140745 & WNT5A-dependent internalization of FZD2,FZD5, and ROR2 & 5 of 13 & $1.05 \mathrm{e}-11$ \\
\hline hsa177504 & Retrograde neurotrophin signaling & 5 of 14 & $1.14 \mathrm{e}-11$ \\
\hline
\end{tabular}

세포와 골수세포가 염증 부위로 이동하는 데 필요하다(Fig. 1). 이 PSGL-1은 P-셀렉틴뿐만 아니라, L-과 E-셀렉틴들의 리간드로 작용할 수 있다[32-34]. P-셀렉틴에 대한 연구를
살펴보면, 각막 상피세포에서 면역 염색법을 이용한 P-셀렉 틴과 PSGL-1의 공동 발현은 염증반응 동안 활성화된 백혈 구가 내피세포 표면에 접착되는 방법과 유사하게 세포 접착 
을 할 수 있다. 이를 PSGL-1과 P-셀렉틴 간의 결합을 억제 하는 KF38789를 이용하여 상피세포에서 비처리대조군과 비 교하였을 때 $40 \%$ 의 현저한 감소를 보였다. 이 결과로부터 PSGL-1 과 P-셀렉틴이 각막 상피세포의 이동에 관여함을 알 수 있다[35]. 그 외에도 동물을 이용한 연구에 따르면 anti-셀렉틴 단일클론항체 또는 PSGL-1과 면역글로불린에 결합한 P-셀렉틴은 동맥 손상 후 호중구 및 혈소판에 부착, 대식섹포 축적 및 신생 혈관 형성을 상당히 감소시킬 수 있 고, 이 결과는 쥐의 자궁내막증 병변에서 유사한 효과를 나타 내고 있다[36].

\section{Selectin family}

셀렉틴의 세 가지 유형인 L-, E- 그리고 P-셀렉틴은 구조 적으로 유사하지만, 발현되는 부위와 조직 분포는 매우 다 르며, 병리 생리학적 과정에서 각각 다양한 역할을 가지고 있다. L-셀렉틴은 백혈구 내에서, E-셀렉틴은 내피세포에서, $\mathrm{P}$-셀렉틴은 혈소판과 내피세포에서 발현 특이성을 가지고 있다. 3 가지 셀렉틴은 백혈구와 혈소판의 접착 상호작용을 일으키는 접착분자이며, L-셀렉틴은 호중구, 단핵세포 및 림 프구가 활성화 된 내피에 부착하고, $\mathrm{E}$-셀렉틴은 호중구의 사이토카인과 활성화된 내피에 부착하며, $\mathrm{P}$-셀렉틴은 내피 세포에 대한 백혈구의 부착을 지원한다[37, 38]. 각 셀렉틴 에 결합하는 리간드는 P-, E-셀렉틴이 주로 백혈구의 리간드 와 결합하며, P-셀렉틴은 혈소판 및 일부 내피세포의 리간드 와 상호 작용을 하고, L-셀렉틴은 활성화된 내피 세포, 림프 절 및 $\mathrm{HEV}$ 의 내피세포에 있는 리간드에 결합한다(Table 2). 모든 셀렉틴은 $\mathrm{SLe}^{\mathrm{x}}$ 에 결합하는 특징을 가지며, $\mathrm{SLe}^{\mathrm{x}}$ 항원 과 $\mathrm{SLe}^{\mathrm{a}}$ 항원이 대표적으로 셀렉틴과 결합한다[39]. 세포 표 면의 글리코실화 변화는 종양의 악성 변형 및 암 진행을 알 수 있는 임상 지표이다. 면역세포와 내피세포에서 렉틴의 발현은 종양세포의 글리칸에 결합하여 종양세포의 진행을 조절할 수 있다. 셀렉틴-매개 상호작용은 암 또는 염증 부위 로 백혈구 동원을 촉진시킨다. 셀렉틴은 림프절 및 종양 부 위뿐만 아니라, 골수-유래 세포를 종양으로 T-세포 모집에도 관여한다. 암이 진행되는 동안 각 셀렉틴의 역할은 P-셀렉틴 이 매개된 혈소판-종양 세포의 상호작용을 통해 종양 세포 유착을 촉진시킨다. L-셀렉틴은 골수-유래 세포 모집을 도와 주고, E-셀렉틴과 함께 효율적인 종양 세포 혈관 외 유출에 기여한다. 따라서, 셀렉틴은 암 진행 동안 면역 반응도 조절 한다. 게다가, 다수의 암 모델에서 셀렉틴의 결핍은 골수-유 래 세포 $(\mathrm{CD} 11 \mathrm{~b}+\mathrm{Ly} 6 \mathrm{C}+\mathrm{Ly} 6 \mathrm{G})$ 에서 종양 전이를 촉진하는 것을 보여준다[5]. 암의 전이에 대한 각 셀렉틴의 생체 내 연구에서 $\mathrm{E}$-셀렉틴은 악성 세포의 결합을 매개하면서 전이 를 촉진시키는 것으로 나타났다. 쥐의 폐에서 채취한 종양 세포를 현미경으로 관찰하였을 때 혈소판이 종양 세포를 고 밀도로 둘러 싸고 있었지만, $\mathrm{P}$-셀렉틴이 결핍된 쥐의 종양
세포는 혈소판이 느슨하게 둘러 싸여 전이를 약화시키는 것 으로 보였다. L-셀렉틴은 암 전이에 대한 기여도가 잘 알려 져 있지 않지만, 백혈구의 L-셀렉틴은 내피세포 표면에서 $\mathrm{L}$-셀렉틴 리간드와 상호작용하여 전이를 촉진시킨다[40].

\section{Conclusion}

각 셀렉틴은 백혈구, 내피세포 및 혈소판에서 발견되며, 이들 세포 유형 사이의 접착을 중재하고, 다양한 세포 및 용 해성 매개체와 함께 작용하여 염증반응의 발달을 조율하는 역할을 가지고 있다. 세 종류의 셀렉틴들은 구조와 기능이 유사한 점이 있지만, 결합하는 리간드와 발현되는 부위가 다른 차이점이 있다. 셀렉틴들은 다양한 천연 및 합성 탄수 화물 구조의 리간드에 결합하여 여러 질병이나 염증반응 등 에 관여한다. 공통적으로 $\mathrm{SLe}^{\mathrm{x}}$ 와 $\mathrm{SLe}^{\mathrm{a}}$ 를 인식하며, 이 분자 의 발현은 종양의 진행 및 전이로 인한 나쁜 결과를 초래하 게 된다. 셀렉틴 리간드 CD44와 PSGL-1가 백혈구의 신호 를 유발하고, 그 외에도 셀렉틴과 결합하는 다양한 리간드 가 인간과 동물의 질병에 영향을 끼친다. 여러 연구를 통해 각 셀렉틴의 종양 세포에 대한 연구 확인하였을 때, 셀렉틴 군이 종양 세포의 전이에 중요한 역할을 한다는 것을 알 수 있다. 이러한 결과로 보아 다양한 질병 과정에서 셀렉틴들 의 발현과 기능을 주의 깊게 평가할 필요가 있다.

\section{Acknowledgements}

본 논문은 농촌진흥청 연구사업(세부과제번호: PJ01268801, “돼지 $\mathrm{CD}$ 유전자군의 구조분석 및 변이발굴”)의 지원에 의 해 이루어진 것입니다. 또한 본 연구는 2019년도 농촌진흥 청 국립축산과학원 전문연구원 과정 지원 사업에 의해 이루 어진 것입니다.

\section{ORCID}

Yunjeong Noh, https://orcid.org/0000-0002-0280-1739

Donghyun Cho, https://orcid.org/0000-0002-3034-8361

Haesu Ko, https://orcid.org/0000-0001-7115-0784

Dajeong Lim, https://orcid.org/0000-0003-3966-9150

Han-Ha Chai, https://orcid.org/0000-0001-7752-3967

\section{References}

1. Medzhitov R. Origin and physiological roles of inflammation. Nature 2008;454:428-435.

2. Yago T, Shao B, Miner JJ, Yao L, Klopocki AG, Maeda K, Coggeshall KM, McEver RP. E-selectin engages PSGL-1 
and CD44 through a common signaling pathway to induce integrin alphaLbeta2-mediated slow leukocyte rolling. Blood 2010;116:485-494.

3. McEver RP. Selectins: initiators of leucocyte adhesion and signalling at the vascular wall. Cardiovasc Res 2015;107: 331-339.

4. Goodison S, Urquidi V, Tarin D. CD44 cell adhesion molecules. Mol Pathol 1999;52:189-196.

5. Borsig L. Selectins in cancer immunity. Glycobiology 2018; 28:648-655.

6. Huang K, Kikuta A, Rosen SD. Myelin localization of a central nervous system ligand for L-selectin. J Neuroimmunol 1994;53:133-141.

7. Imai Y, Lasky LA, Rosen SD. Further characterization of the interaction between L-selectin and its endothelial ligands. Glycobiology 1992;2:373-381.

8. Hafezi-Moghadam A, Thomas KL, Prorock AJ, Huo Y, Ley K. L-selectin shedding regulates leukocyte recruitment. J Exp Med 2001;193:863-872.

9. Malhotra R, Ward M, Sim RB, Bird MI. Identification of human complement factor $\mathrm{H}$ as a ligand for L-selectin. Biochem J 1999;341:61-69.

10. Zak I, Lewandowska E, Gnyp W. Selectin glycoprotein ligands. Acta Biochim Pol 2000;47:393-412.

11. Kawashima H, Li YF, Watanabe N, Hirose J, Hirose M, Miyasaka M. Identification and characterization of ligands for L-selectin in the kidney. I. Versican, a large chondroitin sulfate proteoglycan, is a ligand for L-selectin. Int Immunol 1999; 11:393-405.

12. Rainer TH. L-selectin in health and disease. Resuscitation 2002;52:127-141.

13. Grailer JJ, Kodera M, Steeber DA. L-selectin: role in regulating homeostasis and cutaneous inflammation. J Dermatol Sci 2009;56:141-147.

14. Korniluk A, Kaminska J, Kiszlo P, Kemona H, DymickaPiekarska V. Lectin adhesion proteins (P-, L- and E-selectins) as biomarkers in colorectal cancer. Biomarkers 2017;22: 629-634.

15. Tyrrell D, James P, Rao N, Foxall C, Abbas S, Dasgupta F, Nashed M, Hasegawa A, Kiso M, Asa D, Kidd J, Brandley BK. Structural requirements for the carbohydrate ligand of E-selectin. Proc Natl Acad Sci USA 1991;88:10372-10376.

16. Li SH, Bruns DK, Rumberger JM, Presky DH, Wilkinson VL, Anostario M, Wolitzky BA, Norton CR, Familletti PC, Kim KJ, Goldstein AL, Cox DC, Huang KS. Consensus repeat domains of E-selectin enhance ligand binding. J Biol Chem 1994;269:4431-4437.

17. Weis WI. Lectins on a roll: the structure of E-selectin.
Structure $1994 ; 2: 147-150$.

18. Lawrence MB, Springer TA. Neutrophils roll on E-selectin. J Immunol 1993;151:6338-6346.

19. Berg EL, Magnani J, Warnock RA, Robinson MK, Butcher EC. Comparison of L-selectin and E-selectin ligand specificities: the L-selectin can bind the E-selectin ligands sialyl Le(x) and sialyl Le(a). Biochem Biophys Res Commun 1992;184:1048-1055.

20. Kang SA, Blache CA, Bajana S, Hasan N, Kamal M, Morita Y, Gupta V, Tsolmon B, Suh KS, Gorenstein DG, Razaq W, Rui H, Tanaka T. The effect of soluble Eselectin on tumor progression and metastasis. BMC Cancer 2016;16:331.

21. Steegmaire M, Borges E, Berger J, Schwarz H, Vestweber D. The E-selectin-ligand ESL-1 is located in the Golgi as well as on microvilli on the cell surface. J Cell Sci 1997; 110:687-694.

22. Hidalgo A, Peired AJ, Wild M, Vestweber D, Frenette PS. Complete identification of E-selectin ligands on neutrophils reveals distinct functions of PSGL-1, ESL-1, and CD44. Immunity 2007;26:477-489.

23. Shirure VS, Liu T, Delgadillo LF, Cuckler CM, Tees DF, Benencia F, Goetz DJ, Burdick MM. CD44 variant isoforms expressed by breast cancer cells are functional E-selectin ligands under flow conditions. Am J Physiol Cell Physiol 2015;308:C68-C78.

24. Shirure VS, Renynolds NM, Burdick MM. Mac-2 binding protein is a novel E-selectin ligand expressed by breast cancer cells. PLOS ONE 2012;7:e44529.

25. Gout S, Morin C, Houle F, Huot J. Death receptor-3, a new E-selectin counter-receptor that confers migration and survival advantages to colon carcinoma cells by triggering p38 and ERK MAPK activation. Cancer Res 2006;66:91179124.

26. Carrascal MA, Talina C, Borralho P, Goncalo Mineiro A, Henriques AR, Pen C, Martins M, Braga S, Sackstein R, Videira PA. Staining of E-selectin ligands on paraffinembedded sections of tumor tissue. BMC Cancer 2018; 18:495.

27. Souza JD, Sousa JR, Hirai KE, Silva LM, Fuzii HT, Dias LB, Carneiro FR, Aarao TL, Quaresma JA. E-selectin and P-selectin expression in endothelium of leprosy skin lesions. Acta Trop 2015;149:227-231.

28. Celi A, Pellegrini G, Lorenzet R, De Blasi A, Ready N, Furie BC, Furie B. P-selectin induces the expression of tissue factor on monocytes. Proc Natl Acadl Sci USA 1994;91:8767-8771.

29. Blann AD, Nadar SK, Lip GY. The adhesion molecule P-selectin and cardiovascular disease. Eur Heart J 2003;24: 
2166-2179.

30. Johnson RC, Chapman SM, Dong ZM, Ordovas JM, Mayadas TN, Herz J, Hynes RO, Schaefer EJ, Wagner DD. Absence of P-selectin delays fatty streak formation in mice. J Clin Invest 1997;99:1037-1043.

31. Geng JG, Chen M, Chou KC. P-selectin cell adhesion molecule in inflammation, thrombosis, cancer growth and metastasis. Curr Med Chem 2004;11:2153-2160.

32. Symon FA, Lawrence MB, Williamson ML, Walsh GM, Waston SR, Wardlaw AJ. Functional and structural characterization of the eosinophil P-selectin ligand. J Immunol 1996;157:1711-1719.

33. Vandendries ER, Furie BC, Furie B. Role of P-selectin and PSGL-1 in coagulation and thrombosis. Thromb Haemost 2004;92:459-466.

34. Lorenzon P, Vecile E, Nardon E, Ferrero E, Harlan JM, Tedesco F, Dobrina A. Endothelial cell E- and P-selectin and vascular cell adhesion molecule-1 function as signaling receptors. J Cell Biol 1998;142:1381-1391.

35. Gillies PJ, Richardson NA, Walshe J, Stephenson SA, Dawson RA, Harkin DG. Demonstration of P-selectin expression and potential function in human corneal epithelial cells. Exp Eye Res 2018;176:196-206.

36. Guo SW, Ding D, Geng JG, Wang L, Liu X. P-selectin as a potential therapeutic target for endometriosis. Fertil Steril 2015;103:990-1000.

37. Cheung LS, Raman PS, Balzer EM, Wirtz D, Konstantopoulos $\mathrm{K}$. Biophysics of selectin-ligand interactions in inflammation and cancer. Phys Biol 2011;8:1-14.

38. Bevilacqua MP, Nelson RM. Selectins. J Clin Invest 1993; 91:379-387.

39. McEver RP. Selectins: lectins that initiate cell adhesion under flow. Curr Opin Cell Biol 2002;14:581-586.

40. Konstantopoulos K, Thomas SN. Cancer cells in transit: the vascular interactions of tumor cells. Annu Rev Biomed Eng 2009;11:177-202. 